\title{
Impact of Module Degradation on the Viability of On-Grid Photovoltaic Systems in Mediterranean Climate: The Case of Shymkent Airport
}

\author{
Zhalgas Smagulov, Adil Anapiya, Dinara Dikhanbayeva, Luis Rojas-Solórzano* \\ Department of Mechanical and Aerospace Engineering, School of Engineering and Digital Sciences, Nazarbayev University, Nur- \\ Sultan, Kazakhstan
}

\begin{abstract}
This paper presents the techno-economic feasibility analysis of an on-grid Photovoltaic Solar System (PVSS) subject to Mediterranean climate aging effects. The PVSS under study is considered installed on the roof of Shymkent airport, located in southern Kazakhstan. A PVSS performance degradation rate of 1.48\%-per-annun was considered according to the Mediterranean climate prevailing in the location. A 25-year life-cycle cost analysis comparing the rated vs. de-rated on-grid PVSS led to a positive Net Present Value (NPV), a less than 9-year equity payback, and favorable internal rate of return (IRR) and Benefit-to-Cost (B-C) ratio in both conditions. However, the de-rated PVSS system underperformed in $16.2 \%, 43.5 \%$ and $20 \%$ the IRR, NPV and B-C ratio, respectively. The analysis demonstrates that despite the expected performance degradation associated to climatic aging, a convenient feed-in tariff (FIT) and attractive financial conditions, such as those present in Kazakhstan, conform a robust setting to promote on-grid PVSS in the country.
\end{abstract}

Keywords: Photovoltaic systems; PVSS degradation; Mediterranean climate; renewable energy; solar energy.

Article History: Received: 24 ${ }^{\text {th }}$ Sept 2020; Revised: $4^{\text {th }}$ Nov 2020; Accepted: $8^{\text {th }}$ Nov 2020; Available online: $11^{\text {th }}$ Nov 2020

How to Cite This Article: Smagulov, Z., Anapiya, A., and Dikhanbayeva, D., Rojas-Solórzano L., (2021) Impact of module degradation on the viability of on-grid photovoltaic systems in Mediterranean climate: case of Shymkent Airport. Int. Journal of Renewable Energy Development, 10(1), 139-147.

https://doi.org/10.14710/ijred.2021.33485

\section{Introduction}

Air terminals are a fundamental part of the universal air transport framework, and they support and encourage the number of travelers and the travel industry all around the globe (DeVault et al. 2012). Moreover, even though in recent years there has been an increase in the attention directed towards the ecological effects of human activities, a threat to both the aircraft industry and the air terminal industry is its low capacity to develop and work on its environmental impact in the near future (Salameh 2014). Furthermore, there is also an increased concern on the effects that air terminals have on nature, and the air terminal industry is attempting to have more ecologically responsible air terminals (Fargione et al. 2008). On the other hand, the International Civil Aviation Organization (ICAO) estimates that global greenhouse gas (GHG) emissions derived from the civil aviation industry will rise 4 to 6 times by 2050 compared to the 2010 emissions because of both the increasing number of airlines and new airports construction (Jain et al. 2010).

However, some actions could diminish the environmental impact of air terminals, like the incorporation of energy-saving light-transmitting diodes (Plante et al. 2010). In addition, the use of sun-powered photovoltaic (PV) frameworks - also known as Photovoltaic Solar system (PVSS) - at air terminals is one of the best options because it diminishes the $\mathrm{CO}_{2}$ production while producing energy (ICAO 2014). Additionally, one of the most widely recognized energysaving structures installed on air terminals are on-grid PV boards, which are usually installed on rooftops. That is why installing PVSS clusters on the rooftop can give it both ecological and financial advantages to air terminals (Kellas 2012). Moreover, those PVSS clusters produce fewer $\mathrm{CO}_{2}$, even though their generation, movement, establishment, decommissioning, and reusing produce $\mathrm{CO}_{2}$ emanations. Besides, PV frameworks have a life expectancy of over 20 years and require low maintenance (Kellas 2012). Because of the advantages of PVSS, an increasing number of air terminals over the world have introduced sun-based powered frameworks (Swart et al. 2013). Furthermore, the world's first absolutely sun based controlled airport is the Indian Cochin International Airport. Other examples are both the Hong Kong International Airport and the London Gatwick Airport, which also use solar power plants (Zaihidee et al. 2016). Thus, airports are suitable for the application of PVSS.

On the other hand, PV modules suffer degradation over time, which reduces the generation of electricity during their lifespan and increases the power levelized cost (Yahya et. al 2011). PV systems steadily degrade and

\footnotetext{
* Corresponding author: luis.rojas@nu.edu.kz
} 
Citation: Smagulov, Z., Anapiya, A., and Dikhanbayeva, D., Rojas-Solórzano L., (2021) Impact of module degradation on the viability of on-grid photovoltaic systems in Mediterranean climate: case of Shymkent Airport. Int. Journal of Renewable Energy Development, 10(1), 139-147, doi: 10.14710/ijred.2021.33485

Page | 140

lose their efficiency due to environmental stresses, including high temperature, humidity, and ultraviolet (UV) radiation. For example, Aly et al. (2019) determined that silicon-based PV panels are significantly affected by environmental factors such as ambient temperature, incident irradiance, wind speed and mounting configuration. According to observations gathered from field-aged PVSS, the degradation modes and catastrophic failures of the PVSS are caused by both the cracking and by the delamination (Aly et al. 2019; Kaplani 2012). Such failure modes will reduce the PV module's performance and shorten its service life. In fact, the cracking of the backsheet on the PV panel - that is caused by a reduction in tensile strength - causes a significant volume of moisture to infiltrate, and that is the most devastating mode of backsheet failure recorded to date. Since backsheet cracking enables both water vapor and liquid to penetrate the PV panel, it can have a significant effect on PV module performance and reliability. Thus, to ensure that the PV module retains its output over its lifespan, the estimation of degradation patterns is important.

Therefore, it is necessary to understand the mechanisms of degradation to predict electricity output over the lifetime of the PV modules, as well as to find solutions to prevent and reduce degradation. For these reasons, researchers have tested PVSS reliability, and they have found that, even if PVSS last more than 25 years outdoors, they degrade (Yahya et al. 2011; Chianese et al. 2003; DeGraaff et al. 2011; Wohlgemuth and Kurtz 2011; Vázquez and Rey-Stolle 2008; IEA-PVPS 2013; Halwachs 2017; Maish et al. 1997). Moreover, mechanical stress, moisture, elevated temperature, and ultraviolet radiation can lead to different failures in operation. Furthermore, the reduced solar cell performance due to damage appears even before its warranty finishes (Kato 2011).

On the other hand, there are cosmetic issues that do not affect the performance nor safety of the module (DeGraaff et al. 2011). Nonetheless, cosmetic issues can trigger or enhance other problems as well as reveal other non-visually detectable failures that affect power output. For example, "snail tracks" are discolorations on the solar cell, and even if there is no evidence yet that they cause a significant reduction in module performance, they are indicators of the presence of cell cracks (Parnham et al. 2017). That is important because glass breakage is one of the most frequent defects caused during transportation and deployment of a PVSS. Even if cell cracks do not directly affect cell performance, they still promote or even cause certain types of degradation, such as the deterioration of electrical insulation, corrosion, delamination, among others (DeGraaff et al. 2011). For example, Liu et al. (2019) performed quantitative analysis on two PVSS combining the equivalent-circuit model and optoelectronic characterization methods, and they found that the encapsulant discoloration in PVSS mostly contributes to its degradation. On the other hand, one of the major causes of PV deterioration is extreme climate conditions (Liu et al. 2019), with the degradation of short circuit current (Isc) being the largest contributor to the reduction of the maximum power point (Pmax) in most climatic areas.

The Isc degradation is mainly due to delamination, discoloration, and cracks present in the cells; however, a small percentage can be due to light-induced degradation (LID) and soiling (accumulation of dirt over the panels)
(Bogdanski et al. 2010). In addition, Isc degradation is the largest contributor to the reduction of the maximum power point (Pmax) in desert climates (Smith et al. 2012). A minor factor in the degradation of Isc comes from the fill factor (FF), which is associated with breakage of corrosion and solder bond (Yedidi et al. 2014). Thus, it is necessary to consider PVSS deterioration when studying if the installation of PVSS is feasible in each climate zone, as the climate is a major factor in its performance.

In this paper, the degradation effect due to the Mediterranean climate on the PVSS that would be installed on the roof of the International Airport of Shymkent was analyzed using a life-cycle cost analysis performed in the RETScreen Expert platform (National Resources Canada, 2004). Shymkent is a city located in the southern part of Kazakhstan (Fig.1), with Continental-Mediterranean climate according to the Köppen climate classification (Ontustyk 2019).

The PVSS would be installed on the roof of the airport, and the top view of the airport roof was obtained using the Google Earth Pro software (Fig. 2). A total roof area of $2820 \mathrm{~m}^{2}$ would be covered by PV panels and accessories.

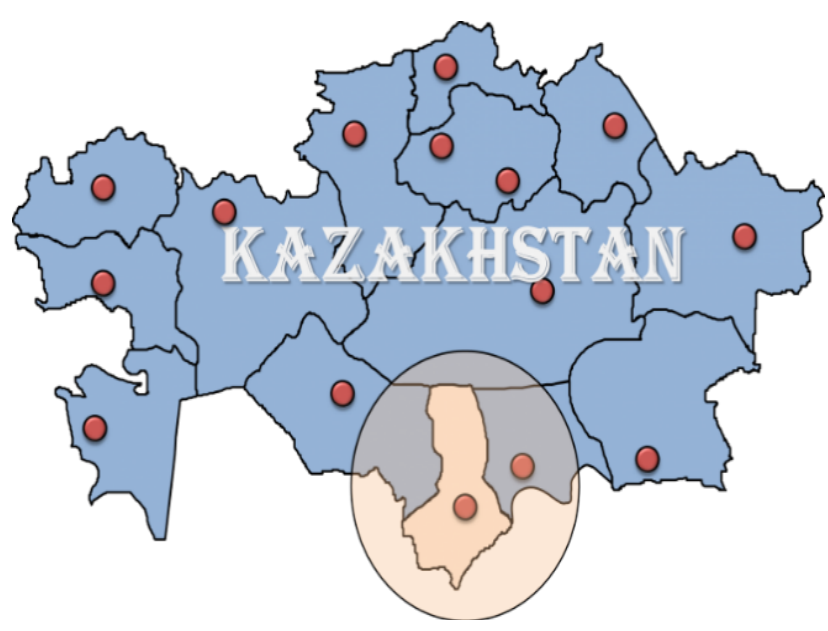

Fig. 1 Location of Shymkent on the Kazakhstan map (Ontustyk 2019).

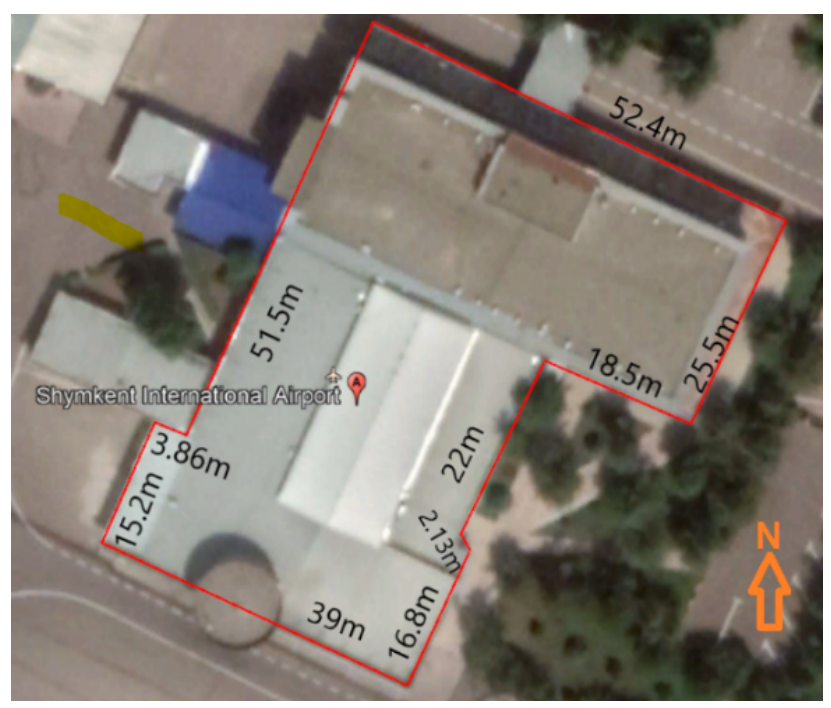

Fig. 2 Scheme of the airport rooftop area to be covered by PV panels (Google Maps view) 


\section{Literature review}

Financially, the degradation of a PV module or system is important because a higher degradation rate negatively affects power production, and it reduces the cash flow. Furthermore, if there are inaccuracies in the determined degradation rates, these can increase the financial risk. Technically, it is also important to understand the degradation mechanisms because they may eventually lead to failure. In PVSS, a 20\% decline is typically considered a failure; however, there is no consensus on the definition of failure for these systems because a highefficiency module with $50 \%$ of degradation may still have a higher efficiency than a non-degraded module that uses a less efficient technology (Weather-Atlas 2019).

As indicated by the National Renewable Energy Laboratory (NREL), PV modules can be affected by conditions like damp heat, UV exposure, thermal cycling, and humidity freeze (Omazic et al. 2019). Moreover, the way that PV modules are affected differ between these elements. For example, thermal cycling can cause weld bond degradations and splits in sun-powered panels; damp heat has been related to the corrosion of cells; humidity freezing can cause failures in the Junction box; UV exposure contributes to staining and back sheet debasement (Peng et al. 2012). When these problems appear, it is difficult to estimate the impact that they have.

Chianese et al. (2003) studied degradations that happened in the midlife of PV modules and estimated that $2 \%$ of the PV modules would not meet the producer's guarantee following 11-12 years of activity. That study found a very high pace of deformity in the interconnections in the module as well as degradations caused by PV module glass breakage.

One of the climates that leads to PVSS degradation is a hot and dry climate because PV modules are exposed to severe stress factors like intensive solar and UV irradiation, extreme temperature cycles, and sand. The most frequent failure processes in a desert climate are discolouration of the EVA encapsulant, followed by delamination above the cell, and a high degree of corrosion (Liu et al. 2019).

Lifetime reduction of PVSS performance is accentuated due to the extreme weather conditions in regions such as in South Africa, where the downtime can last up to four hours a day in the most severe months (Kellas 2012). In arid regions, dust is the main problem for PVSS. Gathered dust of $20 \mathrm{~g} / \mathrm{m}^{2}$ on the PVSS reduces short circuit current, open-circuit voltage, and efficiency by 15 21\%, 2-6\%, and 15-35\%, respectively (Swart et al. 2013).

The installation of PV panels in airports and nearby territories is becoming trendier and taking off worldwide. This combination has many advantages. For example, the airport installations and parking space are usually large, and despite the neighbouring noise from aircraft makes them unusable for many alternative purposes, installing solar panels would be practical and could support part of the airport power demand and also feed the grid.

As one of the examples of successful implementation of solar PV panels in airports we have the San Diego International Airport (SDIA). A system with 5.5 MWp was installed at SDIA with an estimated generation of 9,200 $\mathrm{MWh} /$ year. Moreover, additional enhancements were made such as the installation of $2 \mathrm{MW} / 4 \mathrm{MWh}$ of storage systems for the energy generated. According to the report, it decreases the airport's electricity cost by more than $40 \%$ (Renewable Energy World 2020).

Additionally, the administration of Cochin International Airport in India, which is the 4 th busiest airport in the world serving more than 5 million people annually, has commissioned an on-grid $12-\mathrm{MWp}$ solar PV plant in the airport premises, operating since 2015. The system has been able to generate enough energy to offset the airport annual consumption and with a positive Net Present Value (NPV) of the project (Sukumaran and Sudhakar, 2017). Many other airports in India are partially powered with solar PV systems to date, while Sukumaran and Sudhakar (2017) believe that most of the airports in the country could be fully solar-powered.

Furthermore, according to the Federal Aviation Administration, 500 airports in the USA would qualify the minimum requirements to install in average $2 \mathrm{MWp} P V$ systems each, which could reach $1 \mathrm{GWp}$ of installed capacity. These PV systems could be installed in a relatively short amount of time and could power 750,000 homes (FAA 2020).

Therefore, despite the installation of solar PV power plants in airports is technically viable and trendy, the degradation rate of the photovoltaic panels may adversely impact their economic viability according to the climate zone where the PVSS is installed. Hence, this investigation aims to determine the influence of the Mediterranean climate of Shymkent city in Kazakhstan on the feasibility of installing a PVSS in the local airport.

\section{Methodology}

The techno-economic analysis of the on-grid photovoltaic system is performed using the RETScreen analysis software (National Resources Canada, 2004). It is an intelligent decision support tool that helps to evaluate the performance of renewable energy projects. The platform allowed us to perform the analysis in 5 steps: energy model, cost budgeting analysis, greenhouse gas emission analysis, life-cycle cost analysis (LCCA), and sensitivity \& risk analysis. These steps are described as follows:

- Energy model. This stage requires information regarding feed-in-tariff (FIT) and proposed PVSS, project location, type of energy used in the project, and regional resources. Based on conditions of the present case study, the platform provides the database with horizontal irradiance in situ and the estimation of electricity production using a fixed-slope PV system can be obtained. The calculation is corrected year after year, to include the degradation of PVSS panels accordingly.

- Cost budgeting analysis. This section pertains to the introduction of periodic, annual, and initial costs associated to the PVSS at year zero value.

- Greenhouse gas (GHG) emission analysis. This section provides an estimation of the $\mathrm{CO}_{2 \mathrm{e}}$ emissions avoided by each of the two considered PVSS scenarios (rated PVSS and de-rated PVSS). This analysis complements the financial impact of each solution with its environmental benefits.

- Life-cycle cost analysis (LCCA). This stage represents the model number-crunching using a standard cash flow analysis affected by all input financial parameters associated to the case of study, including: inflation and FIT escalation rates, and the minimum 
return rate expected by investors in this sector (discount rate). The outcome of the LCCA determines for the two scenarios (rated PVSS and de-rated PVSS -subject to photovoltaic panels degradation-) decisionmaking cost-effectiveness indicators (e.g., Snell 1997), including the Net-Present Value (NPV), Internal Rate of Return (IRR), Equity Payback, and Benefit-Cost (BC) ratio. Equations (1) thru (8) show the indicators:

$$
\begin{aligned}
& C_{n}=C_{\text {in }, n}-C_{\text {out }, n} \\
& C_{0}=\text { Incentives }+ \text { Grants }- \text { Initial Cost } \\
& C_{\text {in }, n}=A E E G x \text { FIT }\left(1+r_{e}\right)^{n} \\
& C_{\text {out }, n}=(O \& M+P C)\left(1+r_{i}\right)^{n} \\
& N P V=\sum_{n=0}^{N} \frac{C_{n}}{(1+r)^{n}} \\
& B-C=\frac{N P V+\text { Initial Cost }}{\text { Initial cost }}
\end{aligned}
$$

IRR:

$\sum_{n=0}^{N} \frac{C_{n}}{(1+I R R)^{n}}=0$ (i. e. , "r" needed for NPV $=0$ )

Equity Payback (EP):

$\sum_{n=0}^{E P} C_{n}=0$ (i.e.,year_to_0 cumulated cash flow)

$\begin{array}{ll}\text { Where: } & \\ A E E G & : \text { annual energy exported to the grid } \\ C_{\text {in }, n} & : \text { cash inflow } \\ C_{\text {out }, n} & : \text { cash outflow } \\ N & : \text { lifetime years } \\ N & : \text { a given year within lifetime } \\ R & : \text { discount rate } \\ r_{e} & : \text { FIT annual escalation rate } \\ r_{i} & : \text { inflation rate } \\ O \& M & : \text { annual operating \& maintenance cost } \\ P C & : \text { periodic cost }\end{array}$

- Sensitivity and risk (S\&R) analysis. In this stage, the most determinant factors in the financial outcome of the project are determined. For this purpose, with an estimation of the uncertainty of each input parameter, a multivariable Monte Carlo (MC) analysis is performed to find out which are the most critical input parameters in determining the expected financial outcomes. The MC simulation is a method to develop a S\&R analysis which considers input parameters and randomly selected values within an uncertainty range indicated by the analyst. The MC simulation consists of 2 steps: a) First, for each input parameter selected by the analyst, 500 random samples are generated using a Gaussian distribution with a mean value 0 and a standard deviation of 0.33 . Once these values are generated, they remain fixed. b)Second, for each input parameter, the corresponding random values from (a) are multiplied by the uncertainty indicated by the user (as a percentage) of variability around the nominal value of the given input parameter. As a result, a matrix of 500 $\mathrm{x}$ number of input parameters will be created; therefore, 500 results will be produced in a histogram of frequency. Thus, for a given risk, an associated confidence range of an outcome financial indicator is determined, and its sensitivity to input parameters is graphically expressed through a tornado chart.

\section{Results and analysis}

\subsection{Energy model}

Shymkent is a city that receives a large average yearround daily irradiance in Kazakhstan. For comparison purposes, Table 1 presents the daily average solar irradiance in several cities of the country.

The PV panels to be installed in Shymkent airport are considered tilted $30^{\circ}$ to maximize the average daily radiation received per year, which results in 5.06 $\mathrm{kWh} / \mathrm{m}^{2} / \mathrm{d}$ (see Table 2). Furthermore, the tilted PV arrangement allows rain to clean the solar panels, which reduced our assumed miscellaneous losses to 3\% (Table 3). A total PVSS capacity of $300 \mathrm{kWp}$ was assumed to fit the airport rooftop area of $2820 \mathrm{~m}^{2}$. This capacity was estimated including the needed space for maintenance and inspection between solar panels. The overall characteristics of the PVSS are presented in Table 3.

Malvoni et al. (2017) estimated the performance deterioration of a PVSS that was exposed to Mediterranean climate outdoors using the Classical Seasonal Decomposition (CSD) method. Their experiments showed that the degradation rate of the PVSS was about $1.48 \%$ /year. The CSD is a common technique used to calculate the degradation rate and does not have significant uncertainties. The reduction of the PV output power due to the annual degradation rate was introduced into the energy model with the lifespan of the project being 25 years.

Therefore, the electricity generation during the first year was estimated through the RETScreen platform using the selected technology of PV panels tilted at fixed $30^{\circ}$, including the panel temperature de-rating as per average monthly temperature, the inverter efficiency and the miscellaneous losses previously indicated in Table 3.

From second year and thereafter, the annual generation was decreased year after year to reflect the deterioration of the PV module performance, i.e., the electricity exported to the grid was reduced by $1.48 \%$ in

\begin{tabular}{|c|c|c|}
\hline City & Region & $\begin{array}{l}\text { Daily Solar Radiation } \\
\text { - horizontal } \\
\left(\mathrm{kWh} / \mathrm{m}^{2} / \mathrm{d}\right)\end{array}$ \\
\hline Astana & North & 3.55 \\
\hline Almaty & Southeast & 3.59 \\
\hline Shymkent & South & 4.45 \\
\hline Taraz & South & 4 \\
\hline Kyzylorda & South & 4.21 \\
\hline Uralsk & Northwest & 3.55 \\
\hline Pavlodar & Northeast & 3.51 \\
\hline Karaganda & Central & 3.71 \\
\hline Aktau & Southwest & 3.92 \\
\hline Kokcetav & North & 3.36 \\
\hline Semipalatinsk & East & 3.81 \\
\hline
\end{tabular}
each subsequent year after the first year, as indicated in Fig. 3.

Table 1

Comparison of average daily solar radiation in different Kazakhstan regions

Source: National Resources Canada (2004) 
Table 2

Daily solar radiation for horizontal and tilted PV modules in Shymkent

\begin{tabular}{lcc}
\hline Month & $\begin{array}{c}\text { Daily solar } \\
\text { radiation -horizontal } \\
\mathbf{k W h} / \mathbf{m}^{2 / \mathbf{d}}\end{array}$ & $\begin{array}{c}\text { Daily solar } \\
\text { radiation -tilted } \\
\mathbf{k W h} / \mathbf{m}^{2 / \mathbf{d}}\end{array}$ \\
\hline January & 1.77 & 2.86 \\
February & 2.58 & 3.60 \\
March & 3.95 & 4.81 \\
April & 5.31 & 5.72 \\
May & 6.5 & 6.39 \\
June & 7.24 & 6.84 \\
July & 7.25 & 6.97 \\
August & 6.35 & 6.61 \\
September & 5.11 & 6.04 \\
October & 3.52 & 4.84 \\
November & 2.14 & 3.42 \\
December & 1.52 & 2.47 \\
\hline Annual & $\mathbf{4 . 4 5}$ & $\mathbf{5 . 0 6}$ \\
\hline
\end{tabular}

Source: National Resources Canada (2004)

Table 3

Technical characteristics of PVSS components

\begin{tabular}{ll}
\hline Component or feature & Technical specification \\
\hline Photovoltaic type & Mono-Si \\
Power capacity $(\mathrm{kWp})$ & 300 \\
$\begin{array}{l}\text { Temperature coefficient } \\
\left(\% /{ }^{\circ} \mathrm{C}\right)\end{array}$ & 0.4 \\
Efficiency $(\%)$ & 11 \\
Solar collector area $\left(\mathrm{m}^{2}\right)$ & 2727 \\
Miscellaneous losses $(\%)$ & 3 \\
Inverter efficiency $(\%)$ & $86 \%$ \\
\hline
\end{tabular}

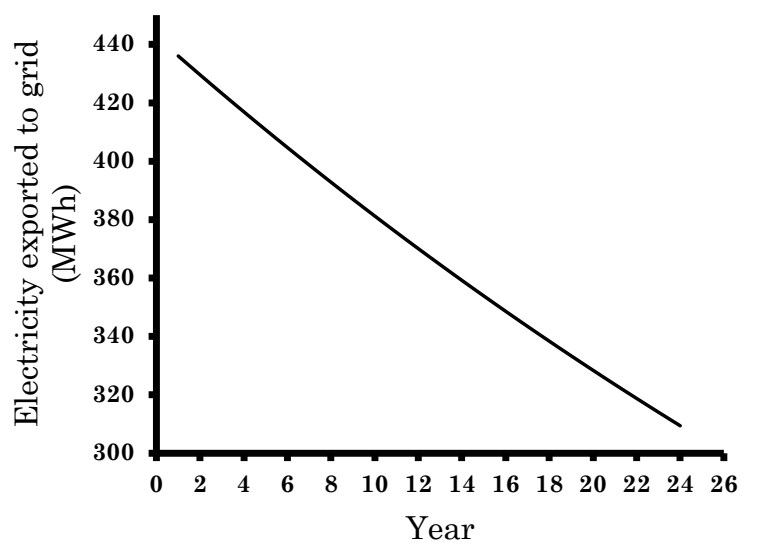

Fig. 3 Electricity exported to grid affected by PV module degradation in each year (de-rated PVSS)

\subsection{Cost budgeting analysis}

The cost of PV modules was estimated in the lower limit of the range 1-3 US $\$ / \mathrm{W}$ suggested by Malvoni et al. (2017), given the fast drop in PV prices experienced in recent years. Hence, the cost of PV panels was taken as $1 \mathrm{US} \$ / \mathrm{W}$ (388.29 KZT/W @ 2019); i.e., 1000 US\$ (388,290 KZT) per one $\mathrm{kW}$.
Table 4

Initial costs for the installation of the PVSS modules in the rooftop of the Shymkent airport

\begin{tabular}{lll}
\hline Initial costs & Quantity & $\begin{array}{l}\text { Unit cost } \\
\text { (KZT) }\end{array}$ \\
\hline Engineering cost & 1 & $1,242,892$ \\
Photovoltaic system & $300 \mathrm{kWp}$ & 388,290 \\
Transportation & 1 & 700,000 \\
Subtotal & & $118,429,892$ \\
Contingencies & $5 \%$ & $5,921,495$ \\
\hline Total initial costs & & $\mathbf{1 2 4 , 3 5 1 , 3 8 7}$ \\
\hline
\end{tabular}

Transportation of all the PV modules was assumed to cost $700,000 \mathrm{KZT}$, and $5 \%$ of contingencies were added. Engineering cost is assumed to be $1 \%$ of the total initial cost $(1,242,892 \mathrm{KZT})$. Therefore, including all these expenses, the total amount of initial cost is $124,351,387$ KZT (see Table 4).

Inverters usually cost $10 \%$ of the total cost (Plante 2014), so it is included as an extra initial cost of $12,435,139$ KZT in this study. A periodic cost for replacement or refurbishment of inverters is considered in year 15 . Operating and maintenance (O\&M) costs are included to cover labour costs of approximately 480,000 KZT per year to consider one technician checking and maintaining the PVSS. This cost includes cleaning the PVSS after snow and dust storms, among other tasks. All annual and nonannual periodic (O\&M) costs are shown in Table 5 .

\subsection{GHG Emission analysis}

The GHG emission factor in Kazakhstan's grid is 0.582 $\mathrm{tCO}_{2 \mathrm{e}} / \mathrm{MWh}$ (The World Bank 2018). However, the World Bank suggests that the electric power transmission and distribution losses (T\&D) in Kazakhstan in 2014 was 7\% per year (Solar Reviews n.d.), and when the T\&D is included, the GHG emission factor increases to 0.626 $\mathrm{tCO}_{2 \mathrm{e}} / \mathrm{MWh}$. In the present analysis, the GHG emission reduction results from the calculated emissions avoided from the grid assuming a zero-emission $\mathrm{kWh}$ injected to the grid by the PVSS. Therefore, the net annual GHG emission reduction is equal to $253.9 \mathrm{tCO}_{2 \mathrm{e}}$ per year during the first year. Notice that even if we include the degradation rate in the PVSS, the emissions would be reduced by the same amount in the first year since the production of electricity is unaffected by PV degradation during the $1^{\text {st }}$-year. However, by the 25 th year, due to its accumulated degradation, the production of electricity by the de-rated PVSS would only avoid $174.9 \mathrm{tCO}_{2 \mathrm{e}}$ of emissions. For the financial analysis, zero GHG reduction credits during the project lifetime were taken.

Table 5

Operating \& Maintenance, and Periodic costs

\begin{tabular}{lll}
\hline $\begin{array}{l}\text { Annual costs } \\
\text { (O\&M) }\end{array}$ & Quantity & Unit cost (KZT) \\
\hline Labor & 2 & 480,000 \\
Subtotal & 960,000 \\
$\begin{array}{l}\text { Periodic costs } \\
\text { (O\&M) }\end{array}$ & $\begin{array}{l}\text { Frequency } \\
\text { (Year) }\end{array}$ & Cost (KZT) \\
$\begin{array}{l}\text { Replacement of } \\
\text { inverters }\end{array}$ & 15 & $12,435,139$ \\
\hline
\end{tabular}


Citation: Smagulov, Z., Anapiya, A., and Dikhanbayeva, D., Rojas-Solórzano L., (2021) Impact of module degradation on the viability of on-grid photovoltaic systems in Mediterranean climate: case of Shymkent Airport. Int. Journal of Renewable Energy Development, 10(1), 139-147, doi: 10.14710/ijred.2021.33485

Page | 144

Table 6

Input parameters in the financial analysis

\begin{tabular}{ll}
\hline Parameter & Value \\
\hline Inflation rate (\%) & 7.31 \\
Discount rate (\%) & 11 \\
Project life (years) & 25 \\
Incentives and grants (KZT) & 0 \\
Electricity export escalation rate (\%) & 7.31 \\
Feed-in Tariff (KZT/kW) & 34 \\
Annual electricity exported to the grid & 436 \\
per year (@year 1) (MWh) & \\
\hline
\end{tabular}

\subsection{Life-cycle cost analysis (LCCA)}

The average inflation rate in Kazakhstan in the last ten years has been $7.31 \%$ per year, and this value was used for this study (Asian Development Bank 2017). On the other hand, the feed-in-tariff (FIT) in Kazakhstan is equal to $34 \mathrm{KZT/KWh}$ (Plecher 2019). The electricity escalation rate was considered as $7.31 \%$, which is the same percentage as the estimated average inflation rate. No loans or grants are considered. Based on the last five years, the discount rate is assumed as $11.1 \%$, according to the National Bank of Kazakhstan (Kursiv 2019). Table 6 presents a summary of the input parameters for the financial analysis. The airport is owned by the governmental "Airport Management Group" company, so there are no taxes to be considered (National Bank of Kazakhstan 2019).

\subsubsection{LCCA for rated or standard PVSS}

Results of the life-cycle cost analysis demonstrate that the base case (rated or standard PVSS) is feasible. As can be seen in Table 7, it was determined that the equity payback period is 6.7 years. In addition, the IRR on equity is $17.9 \%$. Moreover, the NPV is positive and reached a total of $96,158,481 \mathrm{KZT}$, with a B-C ratio of 1.8 .

Table 8 shows the overall cash flow of the project, and it can be seen that the equity payback period of the project would be of seven years; i.e., the total investment would be paid completely in the seventh year of the project. Moreover, in the last year, 80,955,664 KZT would be obtained from the project. In total, $824,550,467 \mathrm{KZT}$ would be earned, which is almost seven times the investment cost.

\subsubsection{LCCA for de-rated PVSS}

The overall cash flow, considering the $1.48 \%$ degradation rate of PV panels, is shown in Table 9. Thus, the electricity exported to the grid decreases $1.48 \%$ each year compared to the previous year.

Table 7

Results of financial analysis for rated PVSS

\begin{tabular}{|ll|}
\hline Financial indicator & Value \\
\hline IRR & $17.9 \%$ \\
Equity payback period & 6.7 years \\
Net present value (NPV) & $96,158,481 \mathrm{KZT}$ \\
Benefit to cost ratio (BCR) & 1.8
\end{tabular}

In this case, the cumulative cash flow becomes positive in the 8th year of the project instead of the 7th year, as it happened for the rated PVSS case. If we compare the cash flow in the 25th year between rated and de-rated PVSS scenarios, it can be observed that the cash flow in the rated PVSS is 244,375,066 KZT higher than in the de-rated PVSS (Tables 8 and 9, respectively), which reflects the expected cash flow reduction when the PV panel degradation is included.

Additionally, Table 9 reflects the annual increase of FIT and O\&M costs associated to escalation and inflation rates (valid similarly for both rated and de-rated scenarios). As a result of the LCCA for the de-rated PVSS, an IRR of $15 \%$, NPV of 54,298,008 KZT, and B-C ratio of 1.44 are obtained (Table 10). Therefore, the positive NPV, higher-than-one $\mathrm{B}-\mathrm{C}$ ratio and favorable IRR demonstrate that a de-rated PVSS in Shymkent airport, due to its Mediterranean climate, is still a techno-economic viable solution. Moreover, given that previous studies about PVSS in southern Kazakhstan did not consider PV degradation (e.g. Assamidanov et al. 2018), the present work reaffirms the primary importance of solar energy projects in the future of the Mediterranean climate zone of Kazakhstan.

Table 8

Cash flow of the project for rated PVSS

\begin{tabular}{|c|c|c|}
\hline Year & $\begin{array}{c}\text { Annual Cash Flow } \\
\text { (KZT) }\end{array}$ & $\begin{array}{c}\text { Cumulative Cash flow } \\
\text { (KZT) }\end{array}$ \\
\hline 0 & $-124,351,387$ & -124351386 \\
\hline 1 & $14,889,584$ & -109461803 \\
\hline 2 & $15,978,013$ & -93483790 \\
\hline 3 & $17,146,005$ & -76337784 \\
\hline 4 & $18,399,378$ & -57938407 \\
\hline 5 & $19,744,373$ & -38194034 \\
\hline 6 & $21,187,686$ & -17006347 \\
\hline 7 & $22,736,506$ & $5,730,159$ \\
\hline 8 & $24,398,545$ & $30,128,704$ \\
\hline 9 & $26,182,079$ & $56,310,782$ \\
\hline 10 & $28,095,989$ & $84,406,771$ \\
\hline 11 & $30,149,805$ & $114,556,576$ \\
\hline 12 & $32,353,756$ & $146,910,333$ \\
\hline 13 & $34,718,816$ & $181,629,148$ \\
\hline 14 & $37,256,761$ & $218,885,909$ \\
\hline 15 & $4,149,674$ & $223,035,582$ \\
\hline 16 & $42,902,785$ & $265,938,367$ \\
\hline 17 & $46,038,979$ & $311,977,346$ \\
\hline 18 & $49,404,428$ & $361,381,774$ \\
\hline 19 & $53,015,892$ & $414,397,666$ \\
\hline 20 & $56,891,353$ & $471,289,019$ \\
\hline 21 & $61,050,111$ & $532,339,130$ \\
\hline 22 & $65,512,875$ & $597,852,005$ \\
\hline 23 & $70,301,866$ & $668,153,870$ \\
\hline 24 & $75,440,932$ & $743,594,802$ \\
\hline 25 & $80,955,664$ & $824,550,467$ \\
\hline
\end{tabular}


Table 9

Cash flow for de-rated PVSS

\begin{tabular}{|c|c|c|c|c|c|c|}
\hline Year & $\begin{array}{l}\text { Electricity exported } \\
\text { to grid (MWh) }\end{array}$ & FIT (\$/MWh) & O\&M (KZT) & Periodic costs & $\begin{array}{c}\text { Annual Cash flow } \\
\text { (KZT) }\end{array}$ & $\begin{array}{l}\text { Cumulative Cash } \\
\text { flow (KZT) }\end{array}$ \\
\hline 0 & & & & & $-124,351,387$ & $-124,351,387$ \\
\hline 1 & 436.00 & $34,000.00$ & $960,000.00$ & & $13,864,000$ & $-110,487,387$ \\
\hline 2 & 429.55 & $36,485.40$ & $1,030,176$ & & $14,642,025$ & $-95,845,362$ \\
\hline 3 & 423.19 & $39,152.48$ & $1,105,481$ & & $15,463,453$ & $-80,381,908$ \\
\hline 4 & 416.93 & $42,014.53$ & $1,186,292$ & & $16,330,686$ & $-64,051,222$ \\
\hline 5 & 410.76 & $45,085.79$ & $1,273,010$ & & $17,246,256$ & $-46,804,965$ \\
\hline 6 & 404.68 & $48,381.56$ & $1,366,067$ & & $18,212,837$ & $-28,592,128$ \\
\hline 7 & 398.69 & $51,918.25$ & $1,465,927$ & & $19,233,245$ & $-9,358,882$ \\
\hline 8 & 392.79 & $55,713.48$ & $1,573,086$ & & $20,310,454$ & $10,951,572$ \\
\hline 9 & 386.97 & $59,786.13$ & $1,688,079$ & & $21,447,596$ & $32,399,169$ \\
\hline 10 & 381.25 & $64,156.50$ & $1,811,477$ & & $22,647,978$ & $55,047,147$ \\
\hline 11 & 375.60 & $68,846.34$ & $1,943,896$ & & $23,915,083$ & $78,962,230$ \\
\hline 12 & 370.05 & $73,879.01$ & $2,085,995$ & & $25,252,586$ & $104,214,816$ \\
\hline 13 & 364.57 & $79,279.56$ & $2,238,481$ & & $26,664,362$ & $130,879,179$ \\
\hline 14 & 359.17 & $85,074.90$ & $2,402,114$ & & $28,154,495$ & $159,033,674$ \\
\hline 15 & 353.86 & $91,293.88$ & $2,577,709$ & $12,435,139$ & $17,292,154$ & $176,325,829$ \\
\hline 16 & 348.62 & $97,967.46$ & $2,766,139$ & & $31,387,294$ & $207,013,807$ \\
\hline 17 & 343.46 & $105,128.88$ & $2,968,344$ & & $33,139,284$ & $240,153,090$ \\
\hline 18 & 338.38 & $112,813.80$ & $3,185,330$ & & $34,988,309$ & $275,141,400$ \\
\hline 19 & 333.37 & $121,060.49$ & $3,418,178$ & & $36,939,685$ & $312,081,085$ \\
\hline 20 & 328.44 & $129,910.01$ & $3,668,047$ & & $38,999,017$ & $351,080,103$ \\
\hline 21 & 323.57 & $139,406.43$ & $3,936,181$ & & $41,172,212$ & $392,252,315$ \\
\hline 22 & 318.79 & $149,597.04$ & $4,223,916$ & & $43,465,495$ & $435,717,810$ \\
\hline 23 & 314.07 & $160,532.59$ & $4,532,685$ & & $45,885,425$ & $481,603,236$ \\
\hline 24 & 309.42 & $172,267.52$ & $4,864,024$ & & $48,438,915$ & $530,042,151$ \\
\hline 25 & 304.84 & $184,860.27$ & $5,219,584$ & & $51,133,249$ & $581,175,401$ \\
\hline
\end{tabular}

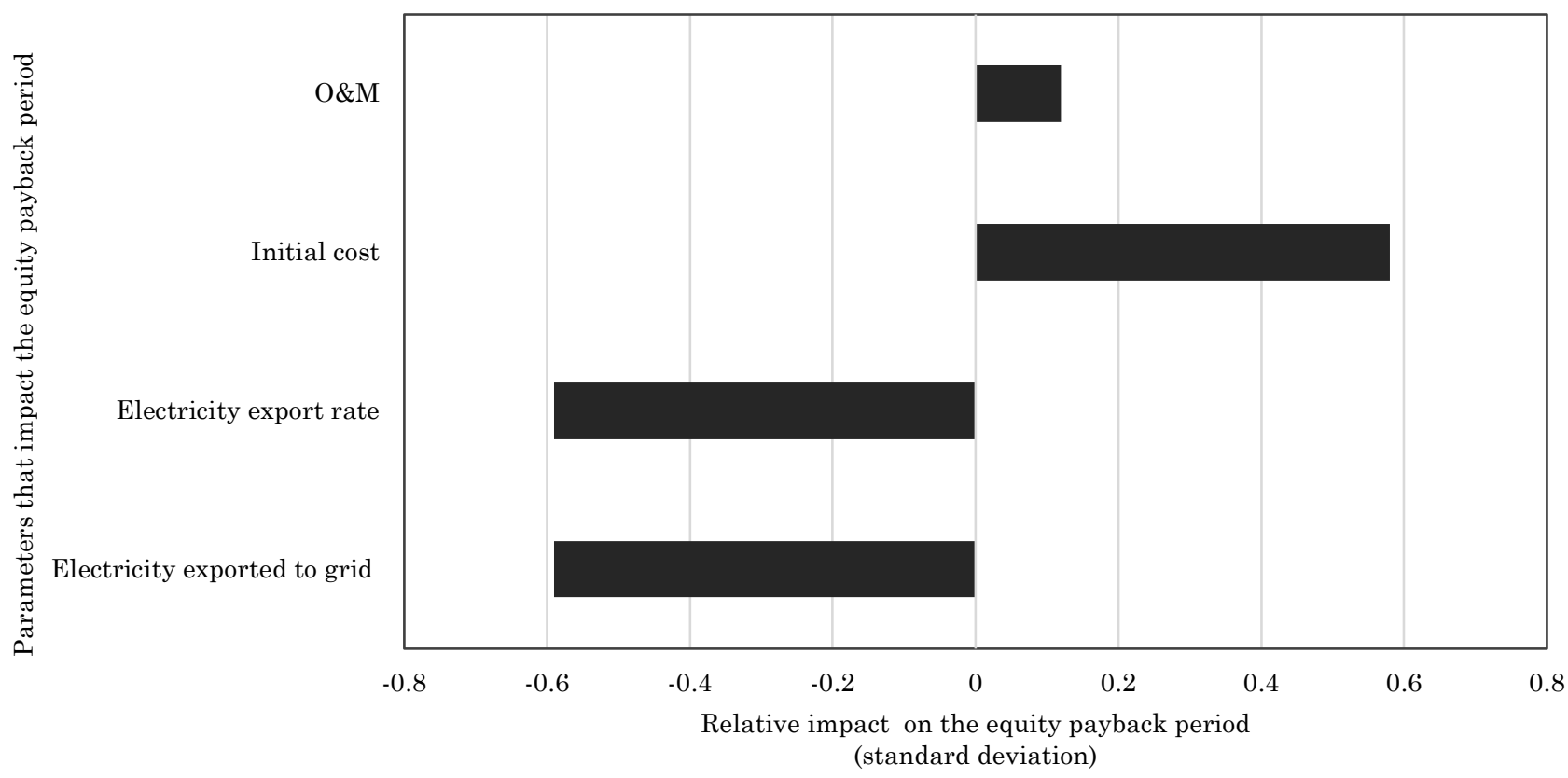

Fig. 4 Relative impact of parameters on the equity payback period for de-rated PVSS (as extracted from RETScreen Expert) 
Citation: Smagulov, Z., Anapiya, A., and Dikhanbayeva, D., Rojas-Solórzano L., (2021) Impact of module degradation on the viability of on-grid photovoltaic systems in Mediterranean climate: case of Shymkent Airport. Int. Journal of Renewable Energy Development, 10(1), 139-147, doi: 10.14710/ijred.2021.33485

Page | 146

Table 10

Comparison of the financial indicators for both Rated and Derated PVSS

\begin{tabular}{llll}
\hline $\begin{array}{l}\text { Financial } \\
\text { indicators }\end{array}$ & $\begin{array}{l}\text { Rated } \\
\text { PVSS }\end{array}$ & $\begin{array}{l}\text { De-rated } \\
\text { PVSS }\end{array}$ & Reduction \\
\hline IRR (\%) & 17.9 & 15 & $16.2 \%$ \\
NPV (KZT) & $96,158,481$ & $54,298,008$ & $43.5 \%$ \\
B-C ratio & 1.8 & 1.44 & $20 \%$ \\
\hline
\end{tabular}

Table 11

Risk analysis of the equity payback for de-rated PVSS

\begin{tabular}{lcc}
\hline $\begin{array}{l}\text { Equity payback risk } \\
\text { parameters }\end{array}$ & Unit & Value \\
\hline Median & yr & 6.7 \\
$\begin{array}{l}\text { Level of risk } \\
\text { Minimum within level } \\
\text { of confidence }\end{array}$ & yr & 5 \\
$\begin{array}{l}\text { Maximum within level } \\
\text { of confidence }\end{array}$ & yr & 6.19 \\
\hline
\end{tabular}

\subsection{Risk and Sensitivity Analysis for de-rated PVSS}

A Monte Carlo analysis was performed with 500 different scenarios within a range of $+/-10 \%$ of uncertainty variation in the input parameters for the de-rated PVSS scenario. Results show that with a risk of $5 \%$ the equity payback period would be between 6.19 and 7.4 years, and the equity payback period would be shorter than ten years (Table 11). On the other hand, according to the tornado chart (see Fig. 4), the initial cost, FIT, and electricity exported to the grid have the higher impact on the equity payback period. Furthermore, higher initial costs would lead to longer equity payback. In contrast, higher values of FIT and electricity exported to the grid would lead to a decrease of the equity payback period. As a final remark, as renewable energy technologies are becoming more efficient and inexpensive over the time, the equity payback period is likely to be reduced in the future which would increase the feasibility of these type of projects (Otyrar 2018).

\section{Conclusion}

On this study, the impact on the performance of on-grid PVSS affected by module degradation in Shymkent, a southern city in Kazakhstan was evaluated. Shymkent has a Mediterranean climate, and the analysis considered the feasibility of installing a PVSS at the roof of the International Airport of this city.

The degradation in PVSS performance due to local climate was estimated to be $1.48 \%$ per year, and its consideration leads to a significant deterioration of the feasibility of the system.

Moreover, if the PVSS degradation is included, the IRR, NPV, and the B-C ratio of the investment would be reduced by $16.2 \%, 43.5 \%$, and $20 \%$, respectively. Thus, the degradation rate of PVSS in Mediterranean climate zones has a significant influence on the technical and financial performance of the system. Nevertheless, even after considering the degradation, our estimations suggest that the PVSS is feasible, and this study can be used as a reference for future PVSS, not only in the Mediterranean climate regions of Kazakhstan but also in any other areas of the world that are subject to a similar climate.

\section{Acknowledgments}

The authors acknowledge the support provided by the School of Engineering and Digital Sciences at Nazarbayev University facilitating the use of computer and academic license of RETScreen Expert decision-support software needed in this study.

\section{References}

Aly, S. P., Ahzi, S. and Barth, N. (2019). Effect of physical and environmental factors on the performance of a photovoltaic panel. Solar Energy Materials and Solar Cells, 200, 109948.

Assamidanov, A., Nogerbek, N. and Rojas-Solórzano. L. (2018). Technical and economic prefeasibility analysis of residential solar PV system in South Kazakhstan. Exergy for A Better Environment and Improved Sustainability. Springer, Chap, 2, 783-792.

Asian Development Bank. (2017). Guidelines for Estimating Greenhouse Gas Emissions of Asian Development Bank Projects. 1-35

Bogdanski, N., W. Herrmann, F. Reil, M. Köhl, K.-.A. Weiss, M. Heck. (2010). PV reliability (cluster II): results of a German four-year joint project: Part II, results of three years module weathering in four different climates. In: Proceedings of the 25th European Photovoltaic Solar Energy Conference and Exhibition/5th World Conference on Photovoltaic Energy Conversion, 6-10. Valencia, Spain.

Chianese, D., A. Realini, N. Cereghetti, A. Rezzonico, E. Bura, G. Friesen, A. Bernasconi. (2003). Analysis of weathered c-Si PV modules, in: IEEE (Ed.) Photovoltaic Energy Conversion. Proceedings of the 3rd World Conference on IEEE, 2922-2926. Osaka, Japan.

DeGraaff, D., R. Lacerda, and Z. Campeau. (2011). Degradation mechanisms in Si module technologies observed in the field; their analysis and statistics. NREL 2011 Photovoltaic Module Reliability Workshop, 20.

DeVault, T. L., J. L. Belant, B. F. Blackwell, J. A. Martin, J. A. Schmidt, L. Wes Burger, and J. W. Patterson. (2012). Airports Offer Unrealized Potential for Alternative Energy Production. Environmental Management 49 (3): 517-522. doi:10.1007/s00267-011-9803-4.

Federal Aviation Administration (FAA) (2020). [online] Available at:<https://www.faa.gov/airports/airport_safety/part139_ce $\mathrm{rt} />$

Fargione, J., J. Hill, D. Tilman, S. Polasky, P. Hawthorne. (2008). Land clearng and the biofuel carbon debt. Science 319:1235-1238.

Halwachs, M., K. Berger, L. Maul, L. Neumaier, Y. Voronko, A. Mihaljevic, and C. Hirschl. (2017). Descriptive statistics on the climate related performance and reliability issues from global PV installations. Proceedings of the 33rd European Photovoltaic Solar Energy Conference and Exhibition, Amsterdam, 1-3.

ICAO. (2014). International Civil Aviation Organization (ICAO). Available at ICAO environmental report. Retrieved December $\quad 14, \quad 2019 \quad$ from https://www.icao.int/environmentalprotection/pages/envreport13.aspx.

Jain, A. K., M. Khanna, M. Erickson, H. Huang. (2010). An integrated biogeochemical and economic analysis of bioenergy crops in the Midwestern United States. GCB Bioenergy 2:217-234.

Jordan, D. C., and S. R. Kurtz. (2013). Photovoltaic degradation rates-an analytical review. Progress in photovoltaics: Research and Applications, 21(1): 12-29. 
Kaplani, E. (2012). Detection of degradation effects in field-aged c-Si solar cells through IR thermography and digital image processing. International Journal of Photoenergy, 2012 (1): $1-11$.

Kato, K. (2011). PVRessQ!: a research activity on reliability of PV systems from an user's viewpoint in Japan. Reliability of Photovoltaic Cells, Modules, Components, and Systems IV. Vol. 8112, 81120K. International Society for Optics and Photonics.

Kellas, A. (2012). Utilizing the solar energy for power generation in Cyprus, 8th Mediterranean Conference on Power Generation, Transmission, Distribution and Energy Conversion (MEDPOWER 2012), Cagliari, pp. 1-7, doi: 10.1049/cp.2012.2012.

Kursiv - business news of Kazakhstan. (n.d.). Как в Казахстане удешевили энергию солнца и ветра [How the sun and wind energy became cheaper in Kazakhstan]. Accessed January 26, 2020. https://kursiv.kz/news/otraslevyetemy/2019-07/kak-v-kazakhstane-udeshevili-energiyusolnca-i-vetra

Liu, Z., M. L. Castillo, A. Youssef, J. G. Serdy, A. Watts, C. Schmid, and T. Buonassisi. (2019). Quantitative analysis of degradation mechanisms in 30-year-old PV modules. Solar Energy Materials and Solar Cells, 200, 110019.

Maish, A. B., C. Atcitty, S. Hester, D. Greenberg, D. Osborn, D. Collier, and M. Brine. (1997). Photovoltaic system reliability. Conference Record of the Twenty Sixth IEEE Photovoltaic Specialists Conference-1997, 1049-1054. IEEE.

Malvoni, M., A. Leggieri, G. Maggiotto, P. M. Congedo, and M. G. De Giorgi. (2017). Long term performance, losses and efficiency analysis of a $960 \mathrm{kWP}$ photovoltaic system in the Mediterranean climate. Energy Conversion and Management, 145, 169-181.

National Bank of Kazakhstan. (2019). Base interest rate of the NBK. Accessed November 1, 2019. https://nationalbank.kz/?docid=107\&switch=english

National Resources Canada. Clean Energy Project Analysis. RETScreen international (2004); 17-33. https://eclass.teicrete.gr/modules/document/file.php/PEGAFV105/RETSCREEN_Textbook_PV.pdf

Omazic, A., G. Oreski, M. Halwachs, G. C. Eder, C. Hirschl, L. Neumaier, and M. Erceg. (2019). Relation between degradation of polymeric components in crystalline silicon PV module and climatic conditions: A literature review. Solar Energy Materials and Solar Cells, 192, 123-133.

Ontustyk. (2019). О регионе [About a region]. СЭЗ «Оңтүстік», Официальный сайт Специальной экономической зоны «Оңтүстік», Шымкент, Специальные экономические зоны Казахстана. https://kazsez.com/en/about-region/

Otyrar. (2018). Аэропорт Шымкента передан в управление города [Shymkent airport transferred to city management]. https://otyrar.kz/2018/11/aeroport-shymkenta-peredanmunicipalitetu/

Parnham, E., A. Whitehead, S. Pain, W. Brennan. (2017). Comparison of accelerated UV test methods with Florida exposure for photovoltaic backsheet materials EU PVSEC. Proceedings of the 33rd European Photovoltaic Solar Energy Conference and Exhibition. Amsterdam.

Peng, P., A. Hu, W. Zheng, P. Su, D. He, K.D. Oakes, A. Fu, R. Han, S.L. Lee, J. Tang, Y.N. Zhou. (2012). Microscopy study of snail trail phenomenon on photovoltaic modules. RSC Advances, 2 (30): 11359.

Plante, R. H. (2014). Solar Energy, Photovoltaics, and Domestic Hot Water: A Technical and Economic Guide for Project Planners, Builders, and Property Owners. Academic Press.

Plante, J., S. Barrett, P. M. De Vita, and R. L. Miller. (2010). Technical guidance for evaluating selected solar technologies on airports. Federal Aviation Administration.
Plecher, H. (2019). Kazakhstan: Inflation rate from 1994 to 2024.https://www.statista.com/statistics/436183/inflationrate-in-kazakhstan/

Realini, A. (2003). Mean Time before Failure of Photovoltaic Modules. Final Report (MTBF Project), Federal Office for Education and Science Tech. Rep., BBW 99.0579.

Renewable Energy World. (2020). San Diego Airport Installs 2 MW/4 Mwh Storage System to Complement Existing PV Array - Renewable Energy World. [online] Available at: $<$ https://www.renewableenergyworld.com/2019/06/27/sandiego-airport-installs-2-mw4-mwh-storage-system-tocomplement-existing-pv-array/\#gref>

Report IEA-PVPS T13-01. (2013). Performance and reliability of photovoltaic systems: Subtask 3.2: review on failures of PV modules. IEA PVPS Task 13, External final draft report IEA-PVPS.

Report IEA-PVPS T1-25. (2014). Trends 2014 in Photovoltaic Applications: Survey report of Selected IEA Countries between 1992 and 2013.

Salameh, Z. (2014). Renewable energy system design.26. https:/doi.org/10.1049/cp.2012.2012

Smith, R. M., D. C. Jordan, S. R. Kurtz. (2012). NREL, outdoor PV module degradation of current-voltage parameters: preprint. Proceedings of the World Renewable Energy Forum, Denver, Colorado.

Snell, M. (1997). Cost-benefit analysis for engineers and planners. London: T. Telford.

Solar Reviews. n.d. How Much Do Solar Panels Cost. Accessed January 25, 2020. https://www.solarreviews.com/solarpanel-cost

Sukumaran, S. and Sudhakar, K., (2017). Fully solar powered airport: A case study of Cochin International airport. Journal of Air Transport Management, 62, pp.176-188.

Swart, J., R. Schoeman, and C. Pienaar. (2013). Ensuring sustainability of PV systems for a given climate region in South Africa. 2013 Africon. doi:10.1109/afrcon.2013.6757638

The World Bank. (2018). Electric power transmission and distribution losses (\% of output). Accessed November 5, 2019.https://data.worldbank.org/indicator/eg.elc.loss.zs?mo st_recent_year_desc=false

Vázquez, M., and I. Rey-Stolle. (2008). Photovoltaic module reliability model based on field degradation studies. Progress in photovoltaics: Research and Applications, 16(5), 419-433.

Wattsap.kz. n.d.. Солнечная панель 300 Вт (24B) [Solar panel 300 W]. Accessed January 25, 2020. https://wattsap.kz/p4832555-solnechnaya-batareya300.html

Weather-Atlas. Monthly weather forecast and Climate Shymkent, Kazakhstan. Accessed October 16, 2019.

Wohlgemuth, J. H., and S. Kurtz. (2011). Reliability testing beyond qualification as a key component in photovoltaic's progress toward grid parity. 2011 International Reliability Physics Symposium, 5E-3. IEEE.

Yahya, A. M., Youm, I., Kader, A. (2011). Behavior and performance of a photovoltaic generator in real time. International Journal of Physical Sciences. 6(18):43614367.

Yedidi, K., S. Tatapudi, J. Mallineni, B. Knisely, K. Kutiche, G. TamizhMani. (2014). Failure and degradation modes and rates of PV modules in a hot-dry climate: results after 16 years of field exposure. Proceedings of the 2014 IEEE 40th Photovoltaic Specialist Conference (PVSC), 3245-3247.

Zaihidee, F. M., S. Mekhilef, M. Seyedmahmoudian, and B.vHoran. (2016). Dust as an unalterable deteriorative factor affecting PV panel's efficiency: Why and how. Renewable and Sustainable Energy Reviews, 65, 1267-1278. 